\title{
Rapid upfront stalk transection for endoscopic resection of pedunculated colorectal lesions using a grasping-type scissor forceps
}

The basic paradigm in endoscopic resection of pedunculated colorectal lesions includes hot snare polypectomy (HSP) with mechanical bleeding prevention techniques [1]. However, when larger, floppy polyps are present and/or the lesions are located in angulations, full endoscopic control of resection may not be guaranteed. Some groups have explored endoscopic submucosal dissection (ESD) for this purpose, and this is potentially of special relevance in cases of short- and wide-stalked lesions [2,3]. By contrast, a more simplified and less time-consuming approach, relying on scissor-type knives, has been reported as an endoscopic bailout after conventional technique failure [4].

This E-Video presents the first clinical report of upfront stalk transection of a colorectal lesion using a grasping-type scissor forceps. The procedure on this sigmoid Ip lesion, estimated at $18 \mathrm{~mm}$ in size, was largely opportunistic, since rectal ESD using the same device had been indicated in the first place in this 83-year-old male patient.

After adequate endoscopic visualization, the lesion is best approached with its head orally orientated and the stalk stretched, as was spontaneously the case here ( Fig. 1 a). Next, this easy-to-implement technique involves submucosal injection of about $3 \mathrm{~mL}$ indigocarmine-saline solution ( $\triangleright$ Fig. 1 b). Unlike in conventional HSP technique, this is followed by immediate mucosal grasping and electrosurgical cutting, using a rotatable, serrated grasping forceps with conductive inner and insulated outer blades (Clutch Cutter, $3.5 \mathrm{~mm}$ blade length; Fuji, Düsseldorf, Germany. Electrocautery, VIO200D;
Erbe Elektromedizin, Tübingen, Germany. Electrocautery settings for cutting: endocut Q: effect 1, duration 3, interval 1 ; for hemostasis: soft coagulation, effect 5, 100 W) ( Fig.1 c; Video 1). This is followed by extension of mucosal cutting by the "paper cutting technique," by which most of the submucosal stalk tissue is likewise addressed, until full stalk resection is accomplished, with hemostasis provided by soft coagulation as needed ( $>$ Fig. $\mathbf{1}$ d,e). In addition, hemoclips are placed at the resection site ( $\triangleright$ Fig.1f) to prevent delayed postresection bleeding. In our case, in vivo and ex vivo assessment indicated en bloc resection and histopathology confirmed wide R0 status.

Most pedunculated colorectal lesions are amenable to conventional techniques, but scissor-type knife-based stalk trans-
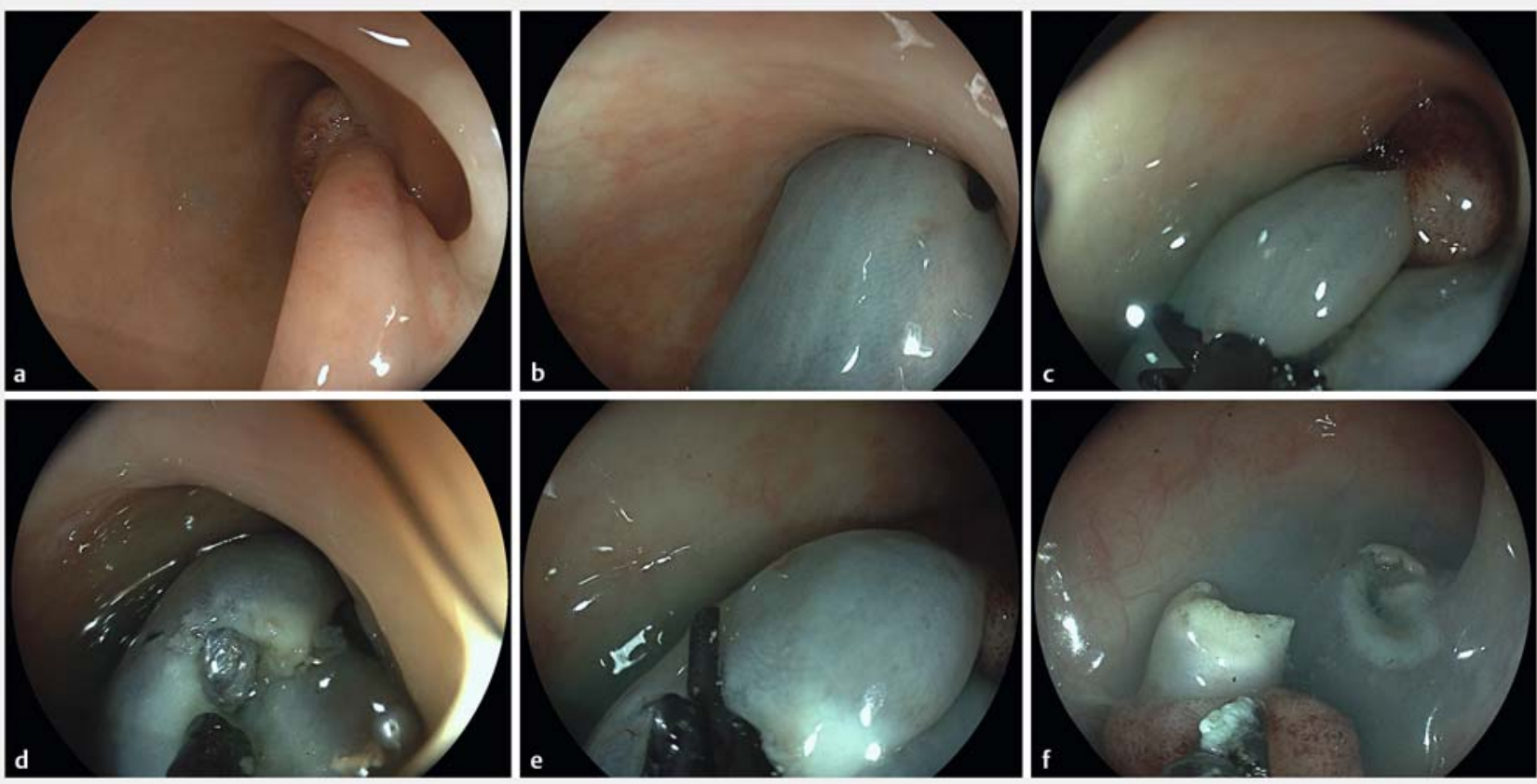

- Fig. 1 a The stalk spontaneously in an orally stretched position, optimal for immediate initiation of the procedure. b The stalk turning blue after injection of $3 \mathrm{~mL}$ indigocarmine-saline solution. c, $\mathbf{d}$ First step of mucosal cutting during stalk transection with the grasping-type scissor forceps perpendicular to the stalk axis. e Extension of the cut using the "paper cutting technique." $\mathbf{f}$ Final result: specimen with wide en bloc status, and unremarkable postresection defect prior to clip application. 


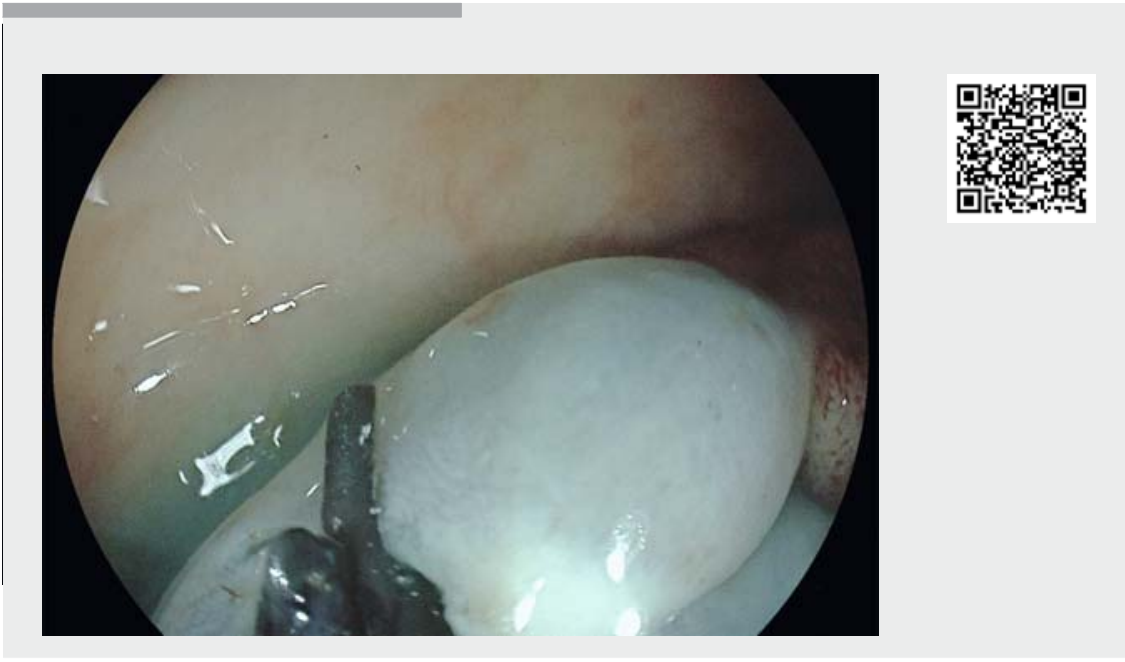

Video 1 Rapid stalk transection for endoscopic resection of pedunculated colorectal lesions using a grasping-type scissor forceps (time from first to final cut: 198s).

ection may be of high value in the future to address large and difficult-to-access Ip lesions.

Endoscopy_UCTN_Code_TTT_1AQ_2AD

\section{Competing interests}

The authors declare that they have no conflict of interest.

The author

\section{Vincent Zimmer ${ }^{1,2}$}

1 Department of Medicine, Marienhausklinik St. Josef Kohlhof, Neunkirchen, Germany

2 Department of Medicine II, Saarland University Medical Center, Saarland University, Homburg, Germany

\section{Corresponding author}

\section{Vincent Zimmer, MD}

Department of Medicine, Marienhausklinik St. Josef Kohlhof, Klinikweg 1-5, 66539 Neunkirchen, Germany Fax: +49-6821-3632624

vincent.zimmer@gmx.de

\section{References}

[1] Ferlitsch M, Moss A, Hassan C et al. Colorectal polypectomy and endoscopic mucosal resection (EMR): European Society of Gastrointestinal Endoscopy (ESGE) Clinical Guideline. Endoscopy 2017; 49: 270-297

[2] Choi YS, Lee JB, Lee EJ et al. Can endoscopic submucosal dissection technique be an alternative treatment option for a difficult giant $(\geq 30 \mathrm{~mm})$ pedunculated colorectal polyp? Dis Colon Rectum 2013; 56: 660-666
[3] Chiba H, Tachikawa J, Arimoto J et al. Endoscopic submucosal dissection of large pedunculated polyps with wide stalks: a retrospective multicenter study. Endoscopy 2020. doi:10.1055/a-1194-4413

[4] Jawaid S, Draganov PV, Yang D. Endoscopic resection of large pedunculated colon polyps using only a scissor-type knife: a case series. VideoGIE 2020; 5: 264-266

\section{Bibliography}

Endoscopy 2021; 53: E253-E254

DOI 10.1055/a-1252-2680

ISSN 0013-726X

published online 23.9.2020

(c) 2020. Thieme. All rights reserved.

Georg Thieme Verlag KG, Rüdigerstraße 14, 70469 Stuttgart, Germany

\section{ENDOSCOPY E-VIDEOS \\ https://eref.thieme.de/e-videos}

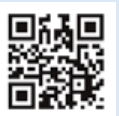

Endoscopy E-Videos is a free access online section, reporting on interesting cases and new

techniques in gastroenterological endoscopy. All papers include a high quality video and all contributions are freely accessible online.

This section has its own submission website at

https://mc.manuscriptcentral.com/e-videos 